\title{
Carnegie completes review of science-government ties
}

Washington. Participants in a five-year effort by the Carnegie Corporation to bring science and government closer together believe that they have improved that relationship somewhat and hold out the promise of even greater success. But critics say that the project failed to recognize the diversity of the US scientific community and that it is very difficult for any non-governmental group to bring about significant and lasting change.

Last week, the Carnegie Commission on Science, Technology and Government issued a summary report on the results of a $\$ 10.7-$ million project begun in 1988 . The

\section{IMAGE UNAVAILABLE FOR COPYRIGHT REASONS}

\section{Joshua Lederberg (left) and William Golden}

commission drew on the knowledge of some 160 senior figures in science and public policy, including former US presidents Jimmy Carter and Gerald Ford, and distributed 208,000 copies of 19 separate reports.

William Golden, co-chair of the commission, says that the group's work will attract "more recognition in the twenty-first century" than it does today. Even so, he says, the commission can claim credit for several short-term victories, including a larger role for the president's science adviser and improved liaison between some government departments and related federal agencies.

Critics say, however, that the commission failed to obtain the views of those outside the academic and political establishment and that any progress has come about independently of its work. Golden, whose science policy roots go back to the presidency of Harry Truman, retorts: "Paternity is always hard to prove".

The commission's first report, Science, Technology and the President, was issued shortly before the election of President George Bush. It called for the appointment of a science adviser at cabinet level and early enough in the new president's term to help him fill other scientific posts, an expanded Office of Science and Technology Policy (OSTP) and access to expert outside advice. Bush fulfilled all those requests except for promptness; that was met by Clinton when he nominated Gibbons on Christmas Eve, a month before taking office himself.

There have been other successes, according to the commission's executive director, David Robinson. The group's proposal for a joint office between the National Science Foundation and the Department of Education has been partially met by the recent signing of a formal "memorandum of understanding" between the two. Robinson also cited the work of the commission's judicial task force in recommending and helping to set up a scientific organization inside the Federal Judicial Center that will provide guidance for judges on the question of interpreting scientific evidence in court (see page 481 ).

Gibbons, speaking last week at the unveiling of the commission's final summary report, said he was struck by how many of those involved are now - like himself - part of the new administration. The commission's defence task force, which called for radical changes in military procurement practice, was led by Bill Perry, the new deputy secretary of defence. "The difficulties of integrating civil and military technology are even greater than envisaged", Perry said last week, "but we will persevere".

Responding to criticism that the commission had said next to nothing about the role of university scientists, Joshua Lederberg, president emeritus of the Rockefeller University in New York and cochairman of the commission, said that any such comments would have been dismissed as special pleading. But more telling criticisms may be the restricted nature of the body from which it drew advice and the lack of any formal mechanism to follow through on its reports.

"They should get credit for the informal aspects of what they did, and their staff work was superb", says Daryl Chubin, a senior associate with the congressional Office of Technology Assessment. "But the process was pretty closed. With any organization that consists almost entirely of white males over 50, you are talking about one particular view of the world, and that worries me." Nearly half of the commission's 17 panels contained no women, for example, and fewer than half a dozen minorities participated in the exercise. Commission officials say that they sought out the most talented people in each field, regardless of gender or race.

As for follow-through, Robinson will continue to run a small office at the corporation to monitor implementation of the commission's proposals over the next two years.

Colin Macilwain

\section{South Africa tightens spending for universities}

Cape Town. The South African budget for this year gives university researchers less than they need to keep pace with inflation and allocates most of the additional spending on science to applied work in government laboratories, dashing hopes of a significant increase in university funding. Not only does the increase of 6 per cent in the science budget fall short of a general increase in spending of 9 per cent and an inflation rate of 10 per cent, but four-fifths of the additional $\$ 13$ million will be allocated to the Council for Scientific and Industrial Research (CSIR), which carries out in-house research on applied science and technology.

The allocation runs counter to the recommendations of a report last year that asked for greater spending on universities (see Nature 356, 9; 1992). The impact of the report appears to have been confined to a reduction of 6 per cent, to $\$ 68$ million, in the allocation to the Agricultural Research Council (ARC). The two largest councils, the $\mathrm{ARC}$ and the CSIR, together get 61 per cent of the science budget.

Friedel Sellschop, deputy vice-chancellor (research) at the University of the Witwatersrand, says that the share of the budget going to universities "remains dangerously inadequate by international standards". Jennifer Thomson, a former director of the CSIR's Laboratory for Molecular and Cell Biology now at the University of Cape Town, interprets the allocation as an attempt by the government to rescue the CSIR in times of recession and a continuing decline in military contracts. Since it was restructured five years ago (see Nature 332, $197 ; 1988$ ), the CSIR has tried to obtain a larger proportion of its income from both the private and public sectors for consulting. In an article co-authored by Johan Lutjeharms, Thomson writes in the current issue of South African Journal of Science that "it would probably be true to say that science as a thriving, innovative, intellectual enterprise within the CSIR is dead".

The reduction in the ARC's subsidy is a belated acknowledgement that agricultural research is overfunded (see Nature 362, $386 ; 1993)$. The allocations to the other councils are:

- CSIR, \$75 million (up 16 per cent);

- Human Sciences Research Council, \$24 million (up 6 per cent);

- Medical Research Council,

$\$ 14$ million (up 7 per cent);

Council for Mineral Technology,

$\$ 18$ million (up 7 per cent);

Foundation for Research Development, $\$ 37$ million (up 11 per cent).

Michael Cherry 